\title{
Leptomeningeal carcinomatosis secondary to gastroesophageal adenocarcinoma: A case report and review of the literature
}

\author{
Ayman A Abdo MD FRCPC ${ }^{1}$, Sylvain Coderre MD FRCPC ${ }^{2}$, \\ Ronald J Bridges MD FRCPC ${ }^{2}$
}

\begin{abstract}
A A A bdo, S Coderre, RJ B ridges. Leptomeningeal carcinomatosis secondary to gastroesophageal adenocarcinoma: A case report and review of the literature. $C$ an J G astroenterol 2002;16(11):807-811.
\end{abstract}

BACKGROU N D : Leptomeningeal carcinomatosis (LC) is a rare metastatic complication of solid tumours. It has been mainly described in association with breast cancer, lung cancer and melanoma.

CA SE PRESEN TATION: A patient presenting with progressive solid food dysphagia with documented adenocarcinoma of the lower esophagus and gastroesophageal junction is reported. One month after the initial diagnosis, the patient developed gradual onset of increasing headache and progressive decrease in the level of consciousness. Computed tomography of the head showed evidence of meningeal enhancement, and cerebrospinal fluid examination showed the presence of adenocarcinoma cells, making the diagnosis of $L C$. The patient died one month after $L C$ was diagnosed.

DISCUSSION : LC is a poor prognostic sign in solid organ malignancies. It usually presents with headache, altered level of consciousness and focal neurological deficits. Diagnosis is established by finding malignant cells in the cerebrospinal fluid and supported by marked meningeal enhancement on computed tomography of the brain. A review of the English literature found only three reported cases of LC secondary to esophageal malignancy.

CONCLUSION: A case of LC complicating esophageal and gastroesophageal junction malignancy is described. A high index of suspicion and early diagnosis may influence the poor outcome of these patients.

Key W ords: Esophageal cancer; G astroesophageal junction cancer; Leptomeningeal carcinomatosis

\section{C arcinomatose des leptoméninges secondaire à un adénocarcinome gastro-oesophagien : exposé de cas et examen de la documentation}

CONTEXTE : La carcinomatose des leptoméninges $(C L)$ est une complication métastatique rare des tumeurs solides. Elle est le plus souvent associée au cancer du sein, au cancer du poumon ou à un mélanome. EXPOSÉ DE CAS : Voici le cas d'un patient qui consulte pour une dysphagie progressive aux solides et chez qui est diagnostiqué un adénocarcinome du bas œsophage et de la jonction gastro-oesophagienne. Un mois après la pose du diagnostic, le patient commence à éprouver des céphalées et une altération de son état de conscience. U ne tomodensitométrie (TDM ) de la tête révèle une prise de contraste des méninges, et l'examen du liquide céphalo-rachidien montre la présence de cellules d'adénocarcinome, d'où établissement du diagnostic de CL. Le patient meurt un mois plustard.

DISCUSSION : La CL est signe de mauvais présage dans les cas de tumeur maligne des organes pleins. Elle se manifeste généralement par des céphalées, une diminution de l'état de conscience et des troubles neurologiques en foyer. La présence de cellules malignes dans le liquide céphalo-rachidien et la prise marquée de contraste des méninges à la TDM signent le diagnostic. La documentation médicale en anglais ne fait état que de trois cas de $C L$ secondaire à un cancer de l'œsophage.

CONCLU SION : L'article décrit un cas de CL compliquant un cancer de I'œsophage et de la jonction gastro-oesophagienne. U ne forte présomption et un diagnostic précoce peuvent influer sur le sombre pronostic de la maladie.

${ }^{1} U$ niversity of $C$ algary and ${ }^{2} D$ epartment of $M$ edicine, D ivision of $G$ astroenterology, $U$ niversity of $C$ algary, $C$ algary, A lberta

C orrespondence: D r Sylvain C oderre, Peter Lougheed C entre, 3500-26th A venue N orth East, C algary, A lberta T 1Y 6J 4.

Telephone 403-943-1512, fax 403-943-8017, e-mail sylvain. coderre@crha-health. ab.ca

Received for publication June 10, 2002. A ccepted September 4, 2002 
eptomeningeal carcinomatosis (LC), or carcinomatous meningitis, is defined as multifocal seeding of the leptomeninges by malignant cells originating from a solid tumour or lymphomatous and leukemic meningitis (1). Although it was thought initially to be rare, this serious complication of cancer is seen with increasing frequency. A utopsy studies reveal that $19 \%$ of cancer patients with neurological symptoms have evidence of meningeal involvement (2). In most large series, breast cancer accounts for $11 \%$ to $64 \%$ of patients, followed by lung cancer ( $14 \%$ to $29 \%$ ) and melanoma ( $6 \%$ to $18 \%$ ) (3).

We describe a rare case of LC secondary to adenocarcinoma of the esophagus and gastroesophageal junction, without apparent central nervous system metastases.

\section{CA SE PRESEN TATION}

A 50-year-old, male construction worker presented with a two-month history of progressive solid food dysphagia accompanied by a $3 \mathrm{~kg}$ weight loss. He had no history of gastroesophageal reflux disease, caustic ingestion or scleroderma. He was a cigarette smoker of half a pack per day for at least 30 years and had been drinking one to two al coholic drinks per day, but had stopped drinking for five years. He was otherwise healthy. The family history was positive for oropharyngeal cancer in his father.

On examination, his weight was $65 \mathrm{~kg}$ and height was $168 \mathrm{~cm}$. His general physical examination including his abdominal examination was normal. He had no clubbing, lymphadenopathy or jaundice.

A $n$ upper gastrointestinal series showed evidence of a fixed irregular narrowing of the distal esophagus.

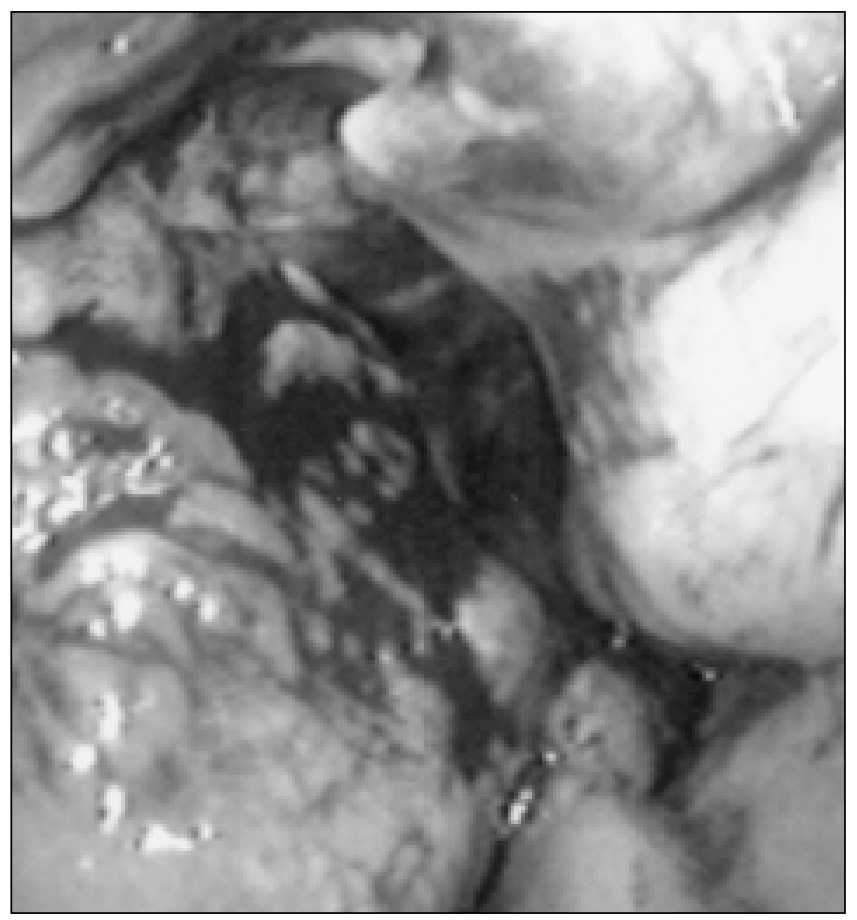

Figure 1) Endoscopic view of the lower esophagus and the gastroesophageal junction showing the cancer
Subsequently, upper gastrointestinal endoscopy was performed, which confirmed the presence of an ulcerated, stenotic mass lesion in the distal esophagus starting at 34 to $40 \mathrm{~cm}$ from the incisors (Figure 1). The stomach appeared to be normal. $0 \mathrm{n}$ retroflexed views of the gastroesophageal junction, the top of the gastric folds appeared to be spared, although the gastroesophageal junction was involved. Biopsies of the lesion revealed a moderately differentiated invasive adenocarcinoma.

Computed tomography (CT) demonstrated an area of severe circumferential thickening involving the distal $6 \mathrm{~cm}$ of the esophagus, extending to the gastroesophageal junction (Figure 2). No regional symphadenopathy was noted. The lungs and liver were clear of metastases. Endoscopic ultrasound of the tumour confirmed the extension of the mass beyond the muscularis mucosa margin at approximately $40 \mathrm{~cm}$. This was consistent with a stage T 3N 0.

Preoperative chemotherapy and radiotherapy wereplanned after consultation with an oncologist and esophageal surgeon.

The patient's dysphagia progressed rapidly. $\mathrm{He}$ was admitted to the hospital because of marked difficulty swallowing liquids and solids, which resulted in volume depletion and malnutrition. At that time he complained of extreme fatigue and a new symptom of mild occipital headache. There was no associated nausea, vomiting or visual disturbances. His level of consciousness was not affected and the neurological examination was normal. He had lost another $5 \mathrm{~kg}$ since presentation. $\mathrm{H}$ is complete blood count, serum electrolytes, and calcium and magnesium levels were all normal. $\mathrm{H}$ is al bumin was low at $32 \mathrm{~g} / \mathrm{L}$. A $n$ enteral feeding tube was placed with radiological guidance. A rrangements were made for home enteral nutrition. Eight days after the feeding tube was inserted, the patient started to show signs of confusion and fluctuating levels of

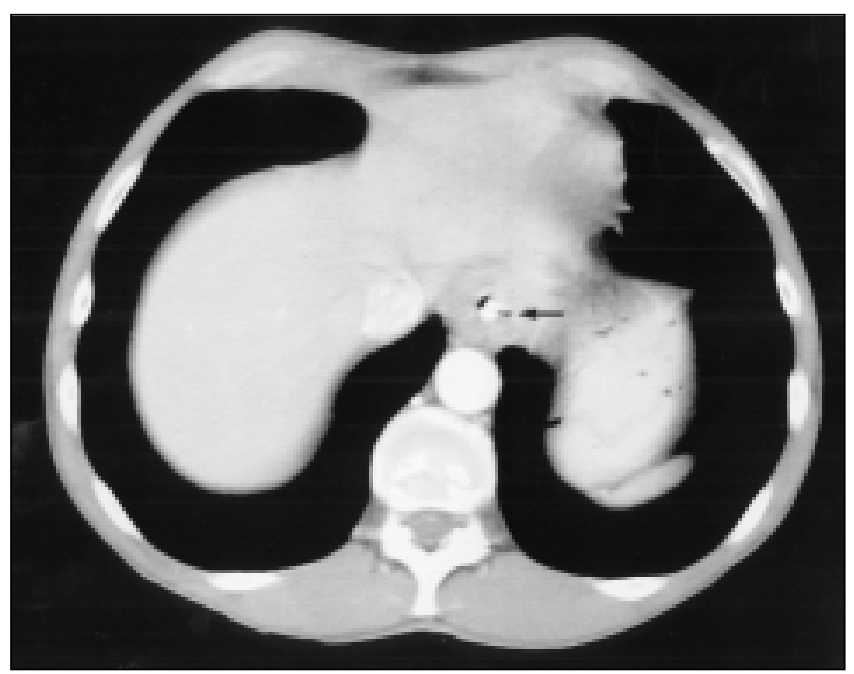

Figure 2) C omputed tomography of the chest showing circumferential thickening of the lower esophagus and the gastroesophageal junction (arrow) 
consciousness. $\mathrm{H}$ is $\mathrm{G}$ lasgow coma scale was fluctuating during the day from normal down to approximately 10 . $\mathrm{H}$ is level of consciousness continued to deteriorate significantly over the next three days and he developed neck stiffness. $\mathrm{He}$ was placed on antibiotics in the form of ceftriaxone $2 \mathrm{~g}$ intravenously daily and a contrast head CT was obtained. This showed evidence of very prominent nodular enhancement involving the meninges overlying the cerebral hemispheres adjacent to the sagittal sinus and along the tentotium cerebelli (Figure 3). A lumbar puncture was performed. The white blood cell count was $35 \times 10^{6} / \mathrm{L}$ ( $8 \%$ polymorphonucleocytes, $84 \%$ lymphocytes, $8 \%$ monocytes), red blood cell count was $2 \times 10^{6} / \mathrm{L}$, glucose was $2.4 \mathrm{mmol} / \mathrm{L}$ ( 2.2 to 3.9 $\mathrm{mmol} / \mathrm{L})$ and protein was $1.35 \mathrm{~g} / \mathrm{L}(0.15$ to $0.45 \mathrm{~g} / \mathrm{L}) . \mathrm{Gram}$ stain and culture were negative. Microscopic examination showed evidence of degenerate atypical cells with features of metastatic adenocarcinoma, confirming the radiological diagnosis of LC. Following oncological and neurological consultations, it was thought that there was no role for chemotherapy or radiotherapy, given the patient's clinical status and the level of consciousness, which had deteriorated further. Palliative care was started. Corticosteroids were given (dexamethasone [Decadron Phosphate Injection, M erck Frosst, Kirkland, Q uebec] 4 mg every $8 \mathrm{~h}$ ). The patient's level of consciousness continued to deteriorate. The patient died shortly thereafter, only two months after the time of his cancer diagnosis and five months after the onset of symptoms.

\section{DISC USSION}

LC is a rare complication of metastatic cancer. It has been reported most commonly in adenocarcinomas of solid organs (4). A pproximately $5 \%$ of all patients with breast cancer (5), $9 \%$ to $25 \%$ of patients with small cell lung cancer (6) and $23 \%$ of patients with melanoma (7) will develop LC. Of tumours from the gastrointestinal tract, it has been described rarely with metastatic adenocarcinoma of the stomach, a complication of this cancer that is thought to be rare (8). It has also been described with malignancies of the gallbladder (9) and cholangiocarcinoma (10). The most common presenting features of LC are headache, changes in mental status, cranial nerve palsies and neck stiffness. These symptoms are thought to result from either obstruction of normal cerebrospinal fluid (CSF) flow by focal tumour deposits, local tumour infiltration in the brain or spinal cord, or alteration in the metabolism of the underlying nervous system.

The mechanism of dissemination of the primary tumour to the leptomeninges is not clear. M ultiple possible routes have been suggested, including direct invasion through the choroidal plexus (11) or leptomeningeal vessels (12), to indirect invasion through nerve roots (13), or retrograde dissemination along perineural lymphatics and sheaths (14). The pattern of meningeal involvement can be focal or diffuse (15).

The diagnosis of $L C$ requires a high index of suspicion. CSF examination is the most valuable test. It should be performed in any patient with unexplained altered neurologi-

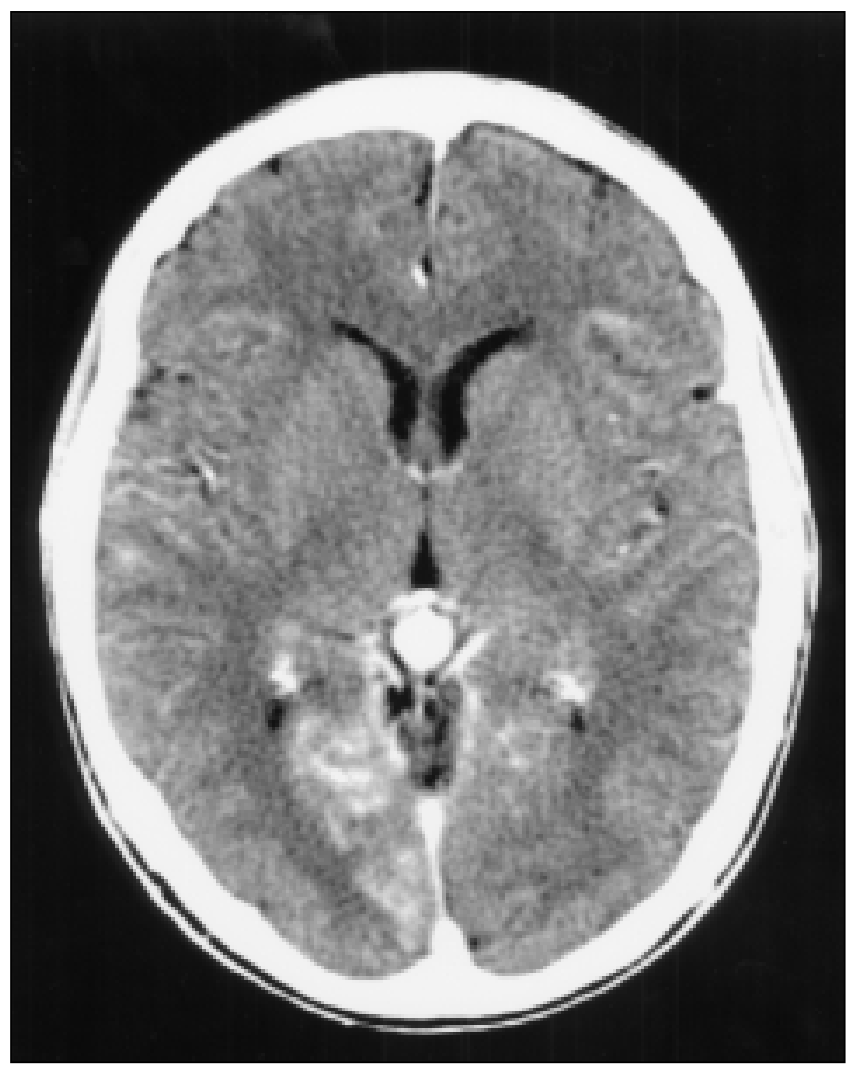

Figure 3) C omputed tomogram of the brain showing prominent nodular enhancement of the meninges

cal status or focal neurological changes. Finding carcinoma cells in the CSF is diagnostic. Other common findings are increased opening pressure, pleocytosis and a modest elevation in the CSF protein (16). CSF may be normal in $5 \%$ of patients. A $n$ elevated CSF carcinoembryonic antigen may also be useful (17). Contrast enhanced CT of the brain or magnetic resonance imaging are positive in approximately $50 \%$ of patients. The most common radiological findings are contrast enhancement of the basilar cisterns, cortical convexities or hydrocephalus without an identifiable mass lesion. These findings are better seen with contrast enhancement.

The prognosis of patients with LC is very poor. This is largely due to the poor prognosis associated with the primary lesion and partially because of difficulties with penetration of the blood brain barrier by available chemotherapy. Estimated median survival is four to six weeks without treatment (16).

Early recognition and treatment of LC will not reverse fixed neurological deficits, but may improve general neurological status and prolong survival. A lthough not shown in randomized and prospective studies, it has been suggested that all patients with overt LC should be offered treatment except those patients with widespread and uncontrolled systemic neoplasia (18).

Standard therapy for LC is debatable. The three important components that are often used are: radiation therapy to the 
TABLE 1

Review of the published cases of Leptomeningeal carcinomatosis (LC) from esophageal cancer compared with the present case

\begin{tabular}{|c|c|c|c|c|}
\hline & Case $1^{*}$ & Case $2^{\star}$ & Case $3^{*}$ & Present patient \\
\hline Age (years) & 51 & 49 & 68 & 50 \\
\hline Sex & Female & Male & Male & Male \\
\hline Type of cancer & Adenocarcinoma & Adenocarcinoma & Squamous cell carcinoma & Adenocarcinoma \\
\hline Location in esophagus & Not clear & Lower third & Middle third & Lower third plus GE junction \\
\hline CNS presentation & $\begin{array}{c}\text { Vomiting, } \\
\text { decreased LOC, } \\
\text { hypertension }\end{array}$ & $\begin{array}{c}\text { Headache, } \\
\text { decreased LOC, } \\
\text { rapid onset of blindness }\end{array}$ & $\begin{array}{l}\text { Sudden bilateral hearing } \\
\text { loss }\end{array}$ & $\begin{array}{c}\text { Headache, } \\
\text { decreased LOC }\end{array}$ \\
\hline $\begin{array}{l}\text { Time from diagnosis to } \\
\text { CNS symptoms }\end{array}$ & 6 months & 4 months & Diagnosed at autopsy & 3 months \\
\hline CSF & $\begin{array}{l}\text { Low glucose, high } \\
\text { protein, malignant cells }\end{array}$ & Normal, no cytology & & $\begin{array}{l}\text { Normal biochemistry, } \\
35 \text { WBC, cancer cells }\end{array}$ \\
\hline Brain CT & $\begin{array}{l}\text { Enhancement in caudate } \\
\text { nucleus }\end{array}$ & Normal & Thickening of meninges & Thickening of meninges \\
\hline Treatment & Steroids, antihypertensives & Symptomatic & $\begin{array}{l}\text { Intrathecal MTX and } \\
\text { cis-platinum }\end{array}$ & Palliation plus steroids \\
\hline Outcome & $\begin{array}{c}\text { Died within } 5 \text { days of } \\
\text { diagnosis }\end{array}$ & $\begin{array}{l}\text { Died within } 1 \text { week } \\
\text { of diagnosis }\end{array}$ & $\begin{array}{l}\text { Died within } 18 \text { days } \\
\text { of diagnosis }\end{array}$ & $\begin{array}{l}\text { Died within } 20 \text { days } \\
\text { of diagnosis }\end{array}$ \\
\hline Autopsy & Confirmed LC & Confirmed LC & Confirmed LC & Not done \\
\hline
\end{tabular}

*Data from reference 28. CNS Central nervous system; CSF Cerebrospinal fluid; CT Computed tomography; GE Gastroesophageal; LOC Level of consciousness; MTX Methotrexate; WBC White blood cell count

affected sites (in an attempt to palliate symptoms), intrathecal chemotherapy and optimal therapy of the primary malignancy. Of the intrathecal agents, methotrexate (M ethotrexate, Faulding, Kirkland, Q uebec) has been the drug most commonly used. If methotrexate is combined with radiation, $50 \%$ of patients may improve initially and the median survival can be prolonged (19). Thiotepa has also been shown to be effective (20). Cytosine arabinoside has also been used mainly in leukemic and lymphomatous meningitis.

G enerally, distant metastasis of esophageal cancer is rare, and metastasis to the central nervous system is unusual (21). M etastasis of esophageal cancer to the brain has been reported in at least 15 case reports $(22,23)$. C entral nervous system (CNS) involvement has been reported as a presenting feature (24), as isolated metastasis to the pineal region (25), as a second primary (26) and as a paraneoplastic syndrome in the form of cerebellar degeneration (27).

In a review of 334 esophagectomies performed in the authors' centre and 293 additional cases from surgical pathology files, $G$ abrielsen et al (28) found brain metastases in about $3.6 \%$ of cases. There was an increased tendency of CN S involvement, with large primary neoplasm, adenocarcinoma of the gastroesophageal junction, or findings of local invasion and lymph node metastases.

In terms of isolated cases of metastasis to the leptomeninges without apparent metastasis in the brain, we found only three case reports published in the English literature. A summary of the key features and comparison of these cases to our case is provided in Table 1.

In the present patient, the deterioration of the level of consciousness was sudden and rapidly progressive. There was no evidence of any apparent metastases on the initial CT of the patient's chest and abdomen, and no apparent CNS metastases on the CT of the head. In consultation with the oncologist, it was decided not to offer the patient chemotherapy or radiotherapy because of his advanced neurological impairment and because of the relative poor prognosis of his primary tumour. The role of steroids in this case is not proven, especially in the absence of hydrocephalus, but we elected to try it in an attempt to decrease cerebral edema and provide some palliation.

\section{CONCLUSIONS}

The fourth case in the English literature of LC in a patient with esophageal and gastroesophageal junction carcinoma has been described. In patients with known esophageal cancer who present with a change in mental status or severe headache, a lumbar puncture should be done early in addition to a contrast enhanced CT of the head to detect LC.

\section{REFEREN CES}

1. G rossman S, Krabak M . Leptomeningeal carcinomatosis. Cancer Treatment Rev 1999;25:103-19.

2. G lass J, M elamed M, Chernik N. M alignant cells in the CSF: The meaning of a positive CSF cytology. N eurology 1979;29:1369-75.

3. Little JR, Dale A J, O kazaki H. M eningeal carcinomatosis: clinical manifestations. A rch N eurol 1974;30:138-43.

4. Wassestrom W, G lass J, Posner J. Diagnosis and treatment of leptomeningeal metastases from solid tumors: experience with 90 patients. C ancer 1983;51:154-60. 
5. Yap H, Yap B, Tashima C. M eningeal carcinomatosis from breast cancer. C ancer 1978;42:283-6.

6. A roney $R$, Dalley $D, C$ han W. M eningeal carcinomatosis in small cell carcinoma of the lung. A m J M ed 1981;71:26-32.

7. A mer M, A I Sarraf, Baker L. M alignant melanoma and central nervous system metastases. C ancer 1978;42:660-8.

8. OIson M, Chernik N, Posner J. Infiltration of the leptomeninges by systemic cancer. A rch N eurol 1974;30:122-37.

9. Gaumann A, M arx J, Bohl J, Kommoss F, Kohler H, Tews D. Leptomeningeal carcinomatosis and cranial nerve palsy as presenting symptoms of a clinical in apparent gallbladder carcinoma. Pathol Res Pract 1999;195:495-9.

10. H uffman J, Yeaman T, Smith J. Leptomeningeal carcinomatosis: a sequela of cholangiocarcinoma. A m Surg 1997;63:310-3.

11. Fischer-W illiams M, Bosanquest F, Daniel P. Carcinomatosis of the meninges: A report of three cases. Brain 1955;78:42-58.

12. Price $R$, Johnson $W$. The central nervous system in childhood leukemia. The arachnoid. Cancer 1973;31:520-33.

13. Griffin J, Thompson R, M itchinson M. Lymphomatous leptomeningitis. A m J M ed 1971;51:200-8.

14. G rain G, Karr J. Diffuse leptomeningeal carcinomatosis. Clinical and pathologic characteristics. N eurology 1955;5:706-22.

15. Kokkoris C, C hristos P. Leptomeningeal carcinomatosis: how does cancer reach the pia arachnoid? C ancer 1983;51:154-60.

16. Wasserstrom W, G lass J, Posner J. Diagnosis and treatment of leptomeningeal metastases from solid tumors: Experience with 90 patients. Cancer 1982;49:759-72.

17. Jacobi $\mathrm{C}$, Reider $\mathrm{H}$, Felgenhauer $\mathrm{K}$. The clinical relevance of locally produced carcino-embryonic antigen in cerebrospinal fluid. J N eurol 1986;233:358-61.

18. Hildebrand J. Prophylaxis and treatment of leptomeningeal carcinomatosis in solid tumors of adulthood. J N eurooncol 1998;38:193-8.

19. Sause W, Crowley J, Eyre H. W hole brain irradiation and intrathecal methotrexate in the treatment of solid tumor leptomeningeal metastases: A Southwest O ncology G roup study. J N eurooncol 1988;6:107-12.

20. Gutin $P, W$ eiss $H$, W iernik $P$. Intathecal thio-TEPA in the treatment of malignant meningeal disease: phase 1-2 study. $C$ ancer 1976;38:1471-5.

21. Kay S. A ten year appraisal of the treatment of squamous cell carcinoma of the esophagus. Surg G ynecol O bstet 1973;117:167-71.

22. Vaquero J, A breu L, C abezudo J. Esophageal carcinoma metastatic to the brain. A m J G astrenterol 1982;77:541-2.

23. Chalif D, Epstein N, Flamm E, Whelan M, Budzilovich G. Intracraneal metastasis of esophageal carcinoma: case report. N eurosurgery 1981:9:331-3.

24. Biswal $B$, Lal P. Brain metastasis as a first presentation of carcinoma of the esophagos: A case report. Indian J M ed Sci 1995;49:210-1.

25. Schuster J, Rostomly R, H ahn C, W inn H. Two cases of esophageal carcinoma metastatic to the pineal region with a review of the literature. Surgical N eurol 1998:49:100-2.

26. Sadanaga N, Kuwanabe M, M ori M, M orioka T, Sugimachi K. Esophageal cancer and second primary brain tumor. Oncology Rep 1998;5:1135-6.

27. Cox P, Vazir M, Petty R, Law S, Dhillon A . Cerebellar cortical degeneration in association with small cell carcinoma of the esophagus. N europathol A pplied N eurobiol 1989;15:175-83.

28. G abrielsen $T$, Eldevik 0 , $O$ rringer $M, M$ arshall $B$. Esophageal carcinoma metastatic to the brain: clinical value and cost effectiveness of routine enhanced head CT before esophagectomy, A m J N euroradiol 1995;16:1915-21. 


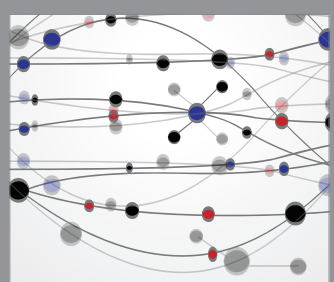

The Scientific World Journal
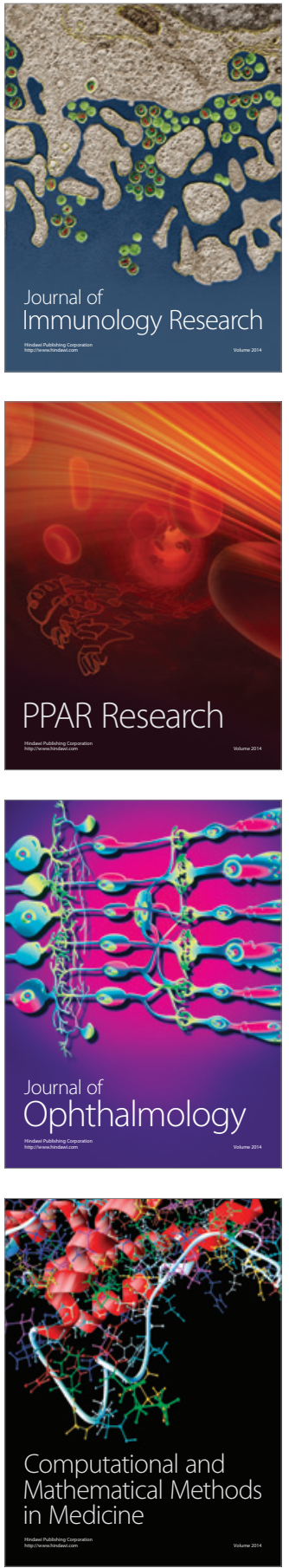

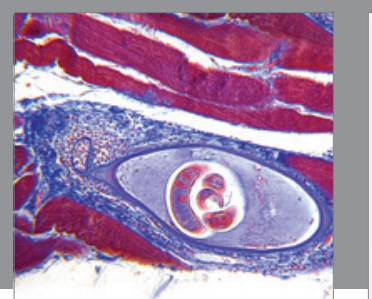

Gastroenterology Research and Practice

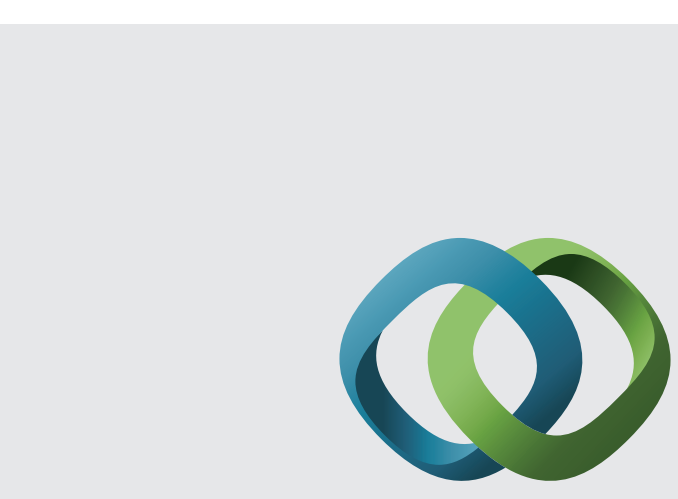

\section{Hindawi}

Submit your manuscripts at

http://www.hindawi.com
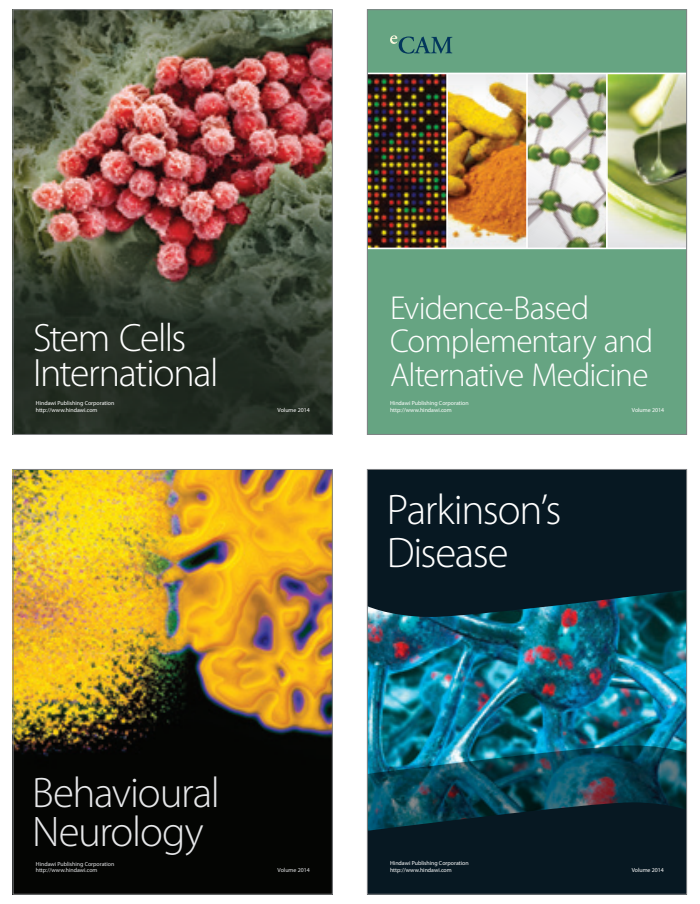
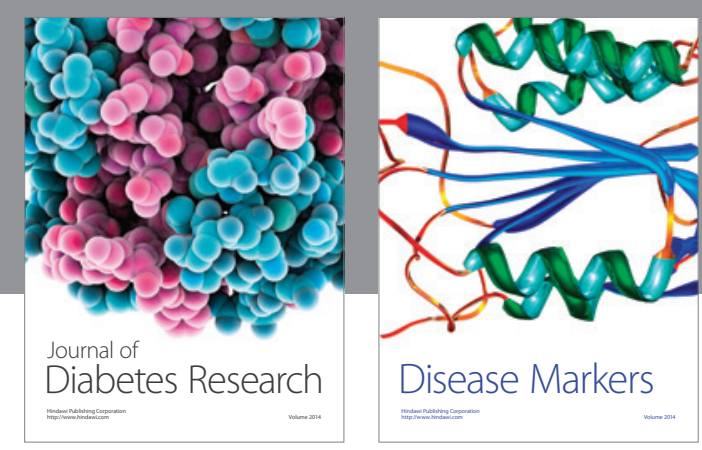

Disease Markers
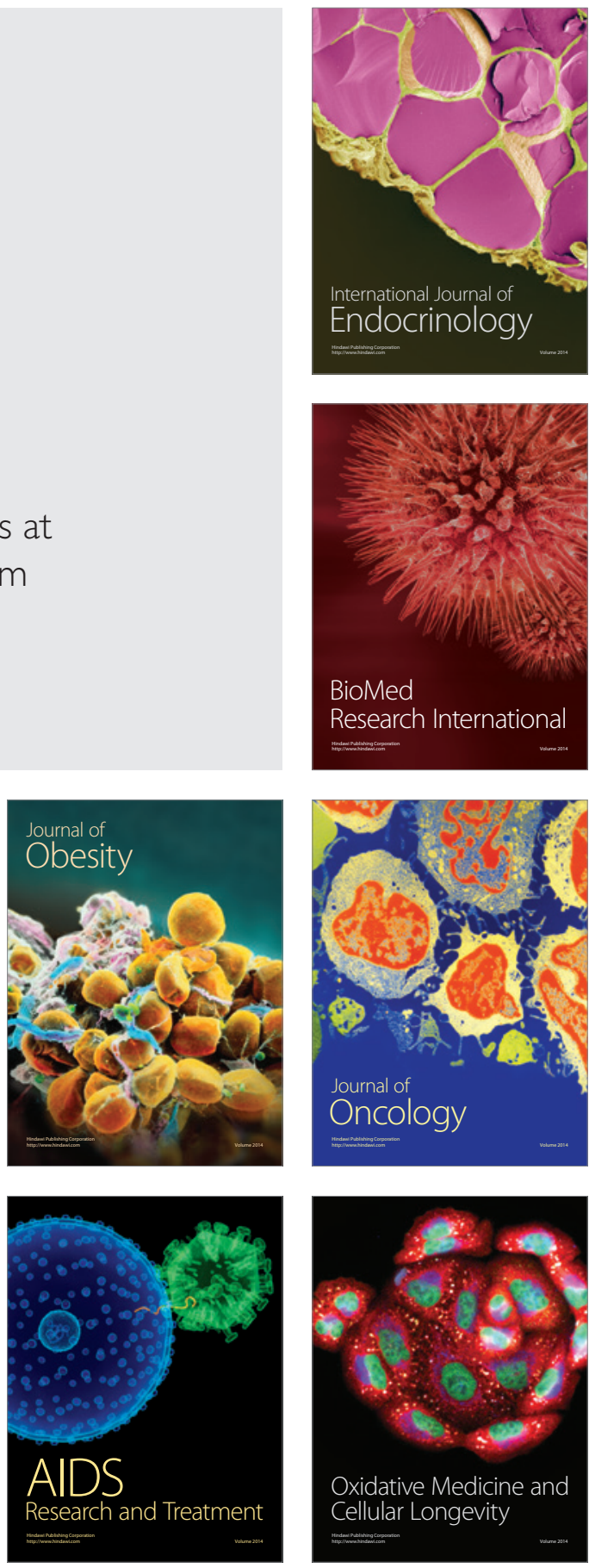